\title{
Asparaginase and Glutaminase Activities of Bacteria
}

\author{
By H. E. WADE, H. K. ROBINSON AND B. W. PHILLIPS \\ Microbiological Research Establishment, Porton, Salisbury, Wiltshire
}

(Accepted for publication 7 September 1971)

\begin{abstract}
SUMMARY
A test-tube method is described for the determinations of L-asparaginase and L-glutaminase in suspensions and extracts of bacteria. An automated modification of the method was used to determine the asparaginase activities of about 200 strains from 78 species and the glutaminase activities of 46 strains from 13 species. Both enzymes were widely distributed and, at $\mathrm{pH} 8.5$, asparaginase was generally the more active. Asparaginase was exceptionally active in some species of Erwinia.
\end{abstract}

\section{INTRODUCTION}

Considerable attention has been paid to the enzyme L-asparaginase (L-asparagine amidohydrolase, EC 3.5.I I) since Broome (196I) showed that it was responsible for the antitumour activity of guinea-pig serum (Kidd, I953); unlike most normal tissue cells some neoplastic cells are unable to survive in the absence of L-asparagine. Mashburn \& Wriston (1964) showed that an asparaginase from Escherichia coli was equally effective against experimental tumours and its clinical evaluation subsequently revealed its special value in the treatment of acute leukaemia. A serologically distinct asparaginase, which produced similar therapeutic effects, was obtained in much higher yield from the plant pathogen Erwinia carotovora (Wade, Elsworth, Herbert, Keppie \& Sargeant, I968; Wade \& Rutter, 1970) and came to light as a result of the survey described in this report.

A parallel interest in L-glutaminase (L-glutamine amidohydrolase, EC 3.5. I .2) has arisen from demonstrations that microbial glutaminases also exhibit antitumour activity (El-Asmar \& Greenberg, I966; Roberts, Holcenberg \& Dolowy, I97I $a, b$; Broome, 197I) and from a report that the complete regression (caused by L-asparaginase) of a mouse leukaemia can be obtained only under conditions in which the circulating L-glutamine is depleted (Riley, I970).

The antitumour effects of both amidases are the subject of recent reviews by Capizzi, Bertino \& Handschumacher (I970), Cooney \& Handschumacher (1970) and Wriston (I97I) and of a report on a symposium held in Paris in 1970 (see Broome, 1971). The present report describes the results of screening bacteria for these enzymes using a test-tube method and an automated Technicon method. The results were briefly described in an earlier report (Wade, Robinson \& Phillips, 1971).

\section{METHODS}

Organisms. Bacteria were generally obtained from national collections: ATCC, American Type Culture Collection, Rockville, U.S.A.; FD, Boots Pure Drug Co. Ltd, Research Department, Antibiotic and Fermentation Division, Nottingham; ICPB, International Collection of Phytopathogenic Bacteria, Davis, California, U.S.A.; MRE, Microbiological Research 
Establishment, Salisbury, Wiltshire; NCDo, National Collection of Dairy Organisms, Shinfield, Berkshire; NCIB, National Collection of Industrial Bacteria, Torry Research Station, Aberdeen; NCMB, National Collection of Marine Bacteria, Torry Research Station, Aberdeen; NCPPB, National Collection of Plant Pathogenic Bacteria, Harpenden, Hertfordshire; RES, Rothamstead Experimental Station, Harpenden, Hertfordshire.

Strains of Serratia marcescens, identified by the prefix JA, were gifts from $\mathrm{Dr}$ A. Alden (University of Sydney).

Media. Plate Count Agar (CMı83), Tomato Juice Agar (CMr13) and Malt Extract Agar (CM59) were obtained from Oxoid Ltd, London. Lister Peptonë Agar contained: I \% (w/v) peptone (Evans Medical Supply Ltd, Runcorn, Cheshire), I \% (w/v) mannitol, $0.5 \% \mathrm{NaCl}$ and $\mathrm{I} \cdot 2 \%(\mathrm{w} / \mathrm{v})$ agar. Yeatex Agar contained $3.5 \%(\mathrm{w} / \mathrm{v})$ Yeatex (light grade yeast extract from the Trent Yeast Extract Co. Ltd, Burton-on-Trent, Staffordshire) and $\mathrm{I} \cdot 2 \%(\mathrm{w} / \mathrm{v})$ agar. Peptone Agar contained $2 \%(\mathrm{w} / \mathrm{v})$ peptone (Evans), $0.5 \% \mathrm{NaCl}$ and $\mathrm{I} \cdot 2 \%(\mathrm{w} / \mathrm{v})$ agar. Nutrient Agar contained 2.5\% (w/v) Nutrient Broth no. 2 (Oxoid, CM 67), $0.4 \%$ Yeast Extract (Oxoid L 2I) and I.2\% (w/v) agar. Potato Agar contained the filtrate from $200 \mathrm{~g}$. of boiled potatoes in I $1.2 \cdot 4 \%$ (w/v) agar at $\mathrm{pH} 7 \cdot 6$.

Culture conditions. The examination of different nutrient agars (Table I) showed that Plate Count Agar induced high levels of L-asparaginase and L-glutaminase. Bacteria generally exhibited the highest activity of L-asparaginase towards the end of a period of maximum growth rate (Roberts, Burson \& Hill, I968; Heinemann \& Howard, 1969; Robison \& Berk, 1969). For screening, therefore, bacteria were grown on this medium at $30^{\circ}$ for 2 days.

Enzyme determination. Amidase activity was determined in $0.05 \mathrm{M}$-borate buffer $\mathrm{pH} 8.5$ $\left(0.05 \mathrm{M}-\mathrm{Na}^{+}\right)$at $37^{\circ}$ in the presence of Io mM-substrate. Two methods were used: one a test tube method using direct Nesslerization and the other an automated Technicon method (Wade \& Phillips, 197I). Both took advantage of the observation (Wade et al. 197I) that the incidence of turbidity which is often encountered in the Nessler reaction, is lower in the presence of EDTA and when alkali is added immediately prior to Nesslerization.

In the test tube assay, bacteria were grown on a solid medium, washed in 10 to $50 \mathrm{vol}$. (relative to the packed bacteria) of $0.15 \mathrm{M}-\mathrm{NaCl}$ containing Io mM-EDTA (disodium salt) and taken up in about Io vol. water, while $9.9 \mathrm{ml}$. of Io mM-L-asparagine (BDH Chemicals Ltd, Poole, Dorset) or Io mM-L-glutamine (chromatographically pure, Koch-Light Laboratories Ltd, Colnbrook, Buckinghamshire) in 0.05 M-borate buffer containing 0.I mM-EDTA were held at $37^{\circ}$. Other preparations of L-glutamine were found unsatisfactory. At zero time, $0.1 \mathrm{ml}$. of the bacterial suspension, containing about $\mathrm{I}$ to 2 international units (i.u.) of enzyme $/ \mathrm{ml}$., was added and quickly mixed. A sample of I ml. was immediately withdrawn and delivered into $2.5 \mathrm{ml}$. of $\mathrm{O} \cdot \mathrm{I} \mathrm{N}$-trichloroacetic acid at room temperature. Further samples were taken at $10 \mathrm{~min}$. intervals up to $60 \mathrm{~min}$.

Each sample was individually mixed with $\mathrm{I} \mathrm{ml}$. of $\mathrm{I} \cdot \mathrm{O} \mathrm{N}-\mathrm{NaOH}$ and after $2 \mathrm{~min} .0 .5 \mathrm{ml}$. of Nessler reagent was added (Koch \& McMeekin, 1924). Automatic dispensers ensured that the treatment of the whole series of samples with each reagent was carried out as quickly as possible.

After $5 \mathrm{~min}$. from the addition of Nessler reagent to the first sample, the optical densities of the subsequent samples were read against it, in optical cells with I or $2 \mathrm{~cm}$. path length and an optical filter with peak transmission at about $400 \mathrm{~nm}$. A plot of optical density against time normally followed a straight line passing through the origin. Standards were prepared by treating $\mathrm{I} \mathrm{ml}$. of $0.25,0.5$ and I $\mathrm{mM}^{-} \mathrm{NH}_{4}^{+}$(ammonium sulphate) with trichloroacetic acid, $\mathrm{NaOH}$ and Nessler reagent in the way described above. The linearity of the plot of optical densities is illustrated in Fig. I to 3 . 
The automated assay is described in detail elsewhere (Wade \& Phillips, 197I). Suspensions in $0.05 \mathrm{M}$-borate buffer $\mathrm{pH} 8.5\left(0.05 \mathrm{M}-\mathrm{Na}^{+}\right)$were taken from a Technicon sampler at a rate of 20 samples/h. and incubated with $10 \mathrm{mM}$-L-asparagine (or L-glutamine) and I mM-EDTA for $20 \mathrm{~min}$. at $37^{\circ}$. The ammonia released passed through the membrane of a Technicon dialyser into $0.025 \mathrm{M}-\mathrm{Na}_{2} \mathrm{SO}_{4}$ and was treated with alkali and Nessler reagent. Standards of 0.1 to $0.8 \mathrm{mM}^{-\mathrm{NH}_{4}^{+}}$were used, corresponding to enzyme activities of 0.005 to $0.04 \mathrm{i} . \mathrm{u} . / \mathrm{ml}$.

The enzyme activities in most species are of such a magnitude that the assay could be carried out in tandem with an automated assay for protein. A loopful of bacteria, taken from a fully-grown culture on the surface of a nutrient agar slope, was suspended in borate buffer ( $10^{7}$ to $10^{8}$ bacteria $/ \mathrm{ml}$.). The two determinations were synchronized so that each sample produced two peaks on a Technicon two-pen recorder: the height of one indicated the amidase activity and the height of the other the protein concentration. From these measurements the specific activities (i.u./mg. protein) could be calculated.

Protein determination. An automated Lowry method was used which operated over the range 4 to $40 \mu \mathrm{g}$. $/ \mathrm{ml}$. (Wade \& Phillips, I97I). Standards were prepared from bovine serum albumin (Fraction V, Armour Pharmaceutical Co. Ltd, Eastbourne, Sussex).

Disruption of bacteria. A suspension (I to $5 \%(\mathrm{v} / \mathrm{v})$ ) in borate buffer $\mathrm{pH} 8.5$ was shaken with $15 \%$ (v/v) Ballotini beads grade no. I2 (Jenkins Scientific Apparatus Ltd, Hemel Hempstead) in a disintegrator (Mickle, I948) in the presence of $0.01 \%(v / v)$ octan-2-ol, at $4^{\circ}$ for $20 \mathrm{~min}$.

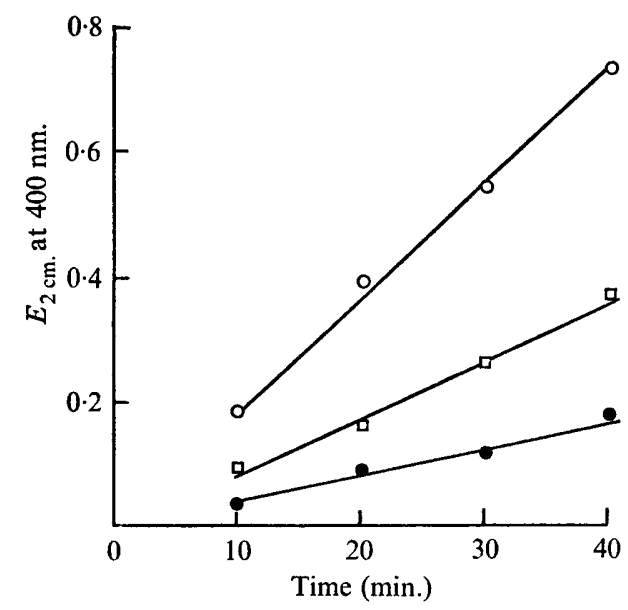

Fig. I. The liberation of ammonia from Io mM-L-asparagine by Serratia marcescens MRE Uk8 grown on Plate Count Agar at $30^{\circ}$ for 2 days and incubated with asparagine at $37^{\circ}$ in $0.05 \mathrm{M}$-borate buffer pH 8.5 (-O- - ) or in $0.05 \mathrm{M}$-acetate buffer $\mathrm{pH} 5.5(---C-)$ or grown in Lister Peptone Agar and incubated in $0.05 \mathrm{M}$-borate buffer pH 8.5 ( $-\square-\square)$. The asparaginase activities were respectively $0.25,0.10$ and $0.06 \mathrm{i} . \mathrm{u} . / \mathrm{mg}$. protein.

\section{Choice of medium}

\section{RESULTS}

Serratia marcescens produced a higher concentration of L-asparaginase when grown on Plate Count Agar than when grown on Lister Peptone Agar (Fig. I). Another comparison, using Erwinia carotovora and the automated method of enzyme determination, confirmed the high production of asparaginase on Plate Count Agar and indicated a broad correlation between the concentration of enzyme produced and the concentration of assimilable carbo- 
hydrate (Table I). The inability of this species to hydrolyse starch probably accounts for the high production of enzyme on Potato Agar.

The production of L-glutaminase appears to follow the same trend (Table I).

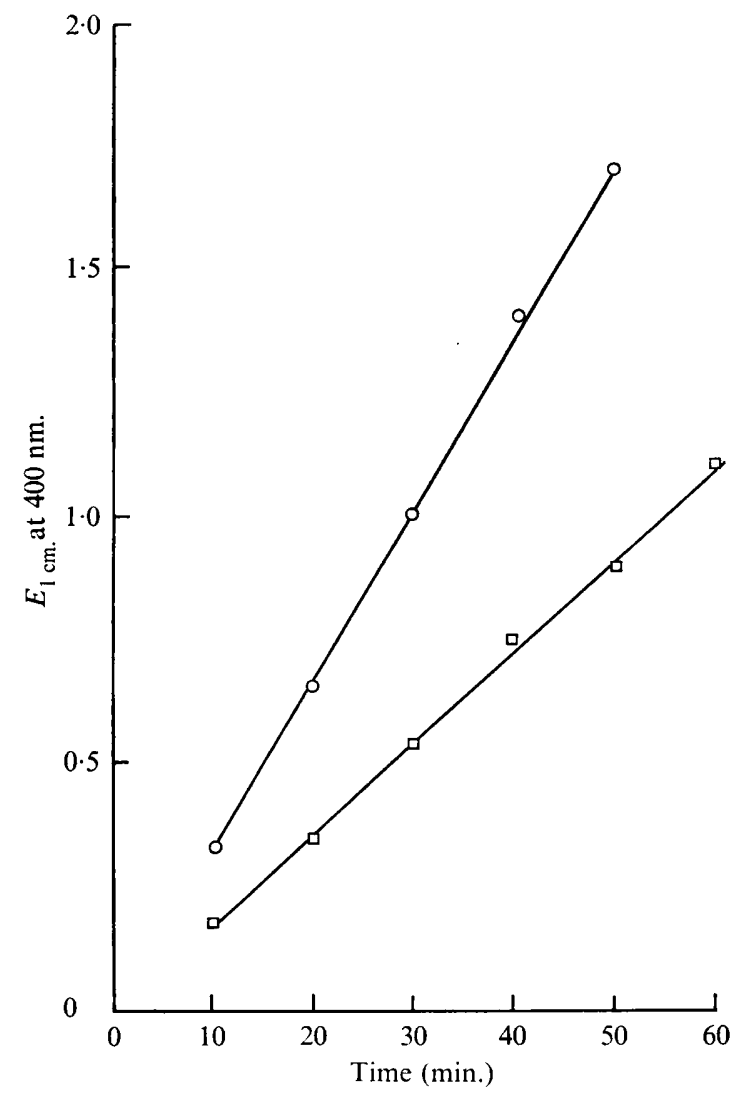

Fig. 2. The liberation of ammonia by Erwinia carotovora NCPPB 1066 grown on Plate Count Agar at $30^{\circ}$ for 2 days, when incubated at $37^{\circ}$ in $0.05 \mathrm{M}$-borate buffer $\mathrm{pH} 8.5$ with $10 \mathrm{mM}$-L-asparagine ( $-\mathrm{O}-\mathrm{O}-$ ) or Io mM-L-glutamine ( $\square-\square-$ ). The concentrations of bacterial protein were 5 and $40 \mu \mathrm{g} . / \mathrm{ml}$. respectively.

Table I. Influence of growth medium upon the production of asparaginase and glutaminase by Erwinia carotovora

Erwinia carotovora NCPPB I066 was trained on each medium by more than three passages. Automated enzyme assays were carried out after 2 days growth at $30^{\circ}$. The two determinations were carried out on different preparations of bacteria.

\begin{tabular}{|c|c|c|c|c|c|}
\hline \multirow[b]{2}{*}{ Agar medium } & \multicolumn{3}{|c|}{ Principal constituents $(\% \mathrm{w} / \mathrm{v})$} & \multicolumn{2}{|c|}{ Enzyme activity (i.u./mg } \\
\hline & Carbohydrate & $\begin{array}{c}\text { Yeast or } \\
\text { beef extract }\end{array}$ & $\begin{array}{l}\text { Tryptone } \\
\text { or peptone }\end{array}$ & $\begin{array}{l}\text { L-Aspara- } \\
\text { ginase }\end{array}$ & $\begin{array}{l}\text { L-Gluta- } \\
\text { minase }\end{array}$ \\
\hline Plate count & O. I (glucose) & 0.25 & 0.5 & $5 \cdot 3$ & 0.23 \\
\hline Yeatex & 一 & $3 \cdot 0$ & - & $4 \cdot 6$ & $0 \cdot 26$ \\
\hline Potato & $<0.04$ (polysaccharide) & - & - & $4 \cdot 4$ & 0.25 \\
\hline Peptone & - & - & 0.5 & $3 \cdot 4$ & 0.26 \\
\hline Nutrient & - & 0.4 & $2 \cdot 5$ & $2 \cdot 7$ & 0.22 \\
\hline Malt extract & $3 \cdot 0$ (malt extract) & - & 0.5 & $0 \cdot 70$ & $0 \cdot 10$ \\
\hline Tomato juice & $2 \cdot 0$ (tomato extract) & - & $2 \cdot 0$ & 0.69 & 0.08 \\
\hline
\end{tabular}




\title{
Reliability of amidase determinations
}

Ammonia was released at a uniform rate during the degradation of L-asparagine and L-glutamine by Erwinia carotovora (Fig. 2) and of L-asparagine by Serratia marcescens (Fig. I) and Escherichia coli (Fig. 3). Other buffers such as formate at pH 3.5, acetate at $\mathrm{pH} 4.5$, phosphate at $\mathrm{pH} 6.5$ to 7.5 (prepared with $0.05 \mathrm{M}-\mathrm{NaOH}$ ) and tris at $\mathrm{pH} 8$ (prepared with $0.05 \mathrm{M}-\mathrm{HCl}$ ) could also be used in the test tube method without interference with the Nessler reactions. The values obtained were within $10 \%$ of those obtained from the automated method when comparisons were made with suspensions of bacteria or preparations of purified L-asparaginase.

\section{Table 2. Reliability of the asparaginase activities of whole bacteria as a measure of the total enzyme present}

\begin{abstract}
Bacteria were grown at $30^{\circ}$ for 2 days on Plate Count Agar in two Petri dishes, washed in $5 \mathrm{ml}$. of borate buffer pH 8.5 and made up to $9 \mathrm{ml}$. in buffer. One half of each suspension was disrupted in a Mickle (1948) disintegrator. A supernatant fraction was obtained by centrifuging at $1000 \mathrm{~g}$ for $20 \mathrm{~min}$. Enzyme activity was determined by the automated method.
\end{abstract}

\begin{tabular}{|c|c|c|c|}
\hline \multirow[b]{2}{*}{ Bacterium } & \multirow[b]{2}{*}{$\begin{array}{l}\text { Enzyme activity } \\
\text { of whole organisms } \\
\text { (i.u./mg. protein) }\end{array}$} & \multicolumn{2}{|c|}{ Enzyme activity of disrupted organi } \\
\hline & & $\begin{array}{l}\text { Unfractionated } \\
\text { (i.u./mg. protein) }\end{array}$ & $\begin{array}{l}\text { Supernatant } \\
\text { fraction ( } \% \text { of } \\
\text { unfractionated } \\
\text { activity) }\end{array}$ \\
\hline $\begin{array}{l}\text { Pseudomonas fluorescens } \\
\text { NCTC } 8248\end{array}$ & 0.15 & 0.12 & $9 I$ \\
\hline $\begin{array}{l}\text { Alcaligenes viscolactis } \\
\text { ATCC } 9036\end{array}$ & $0 \cdot 19$ & $0 \cdot 24$ & 70 \\
\hline $\begin{array}{l}\text { Escherichia coli } \\
\text { NCIB 900I }\end{array}$ & $0 \cdot 1 \mathrm{I}$ & O.II & 100 \\
\hline $\begin{array}{l}\text { Erwinia carotovora } \\
\text { NCPPB I066 }\end{array}$ & $4 \cdot 5$ & $4 \cdot 7$ & 100 \\
\hline $\begin{array}{l}\text { Serratia marcescens } \\
\text { MRE UK8 }\end{array}$ & $0 \cdot 18$ & $0 \cdot 18$ & 94 \\
\hline $\begin{array}{l}\text { Proteus vulgaris } \\
\text { MRE } 402\end{array}$ & $0.3 \mathrm{I}$ & $0 \cdot 13$ & 86 \\
\hline $\begin{array}{l}\text { Micrococcus lysodeikticus } \\
\text { ATCC } 4698\end{array}$ & 0.12 & 0.08 & 93 \\
\hline $\begin{array}{l}\text { Bacillus subtilis } \\
\text { MRE strain }\end{array}$ & 0.5 & 0.47 & 80 \\
\hline $\begin{array}{l}\text { B. megaterium } \\
\text { NCTC } 2607\end{array}$ & $0.3 \mathrm{I}$ & $0 \cdot 19$ & 84 \\
\hline
\end{tabular}

Some species were examined more closely to determine to what extent the values obtained were a reliable measure of the total enzyme present in the bacteria. The results (Table 2) suggest that in fact slightly higher values are obtained from whole organisms than from disrupted preparations. Of the nine species examined, only Alcaligenes viscolactis exhibited a higher level of activity when disrupted.

Determinations carried out on disrupted preparations may be subject to error through the assimilation of ammonia or through the instability of the enzymes. When the release of ammonia from L-asparagine was followed in a suspension of Escherichia coli and in a cellfree extract a lag was observed in the latter which could not be avoided by incubating the extract for $20 \mathrm{~min}$. (Fig. 3).

Varying degrees of instability of L-asparaginase were observed in preparations of disrupted bacteria (Table 2). Instability was very pronounced in Bacillus megaterium; after 
storage for 2 days at 2 to $4^{\circ}$ the preparation had lost about $80 \%$ of its activity. A similar preparation from Escherichia coli lost $30 \%$ of its activity. When $E$. coli ATCC II 303 was disrupted in a Hughes Press (Hughes, 195I) and fractionated into a cell-wall fraction, a ribosome fraction and a soluble fraction (Wade, 196I), L-asparaginase could be recovered without loss from the soluble fraction where it was unstable particularly when exposed to air. Under aerobic conditions, glutathione and cysteine offered some protection but EDTA was more effective (Table 3) probably by inhibiting metal-dependent proteinases.

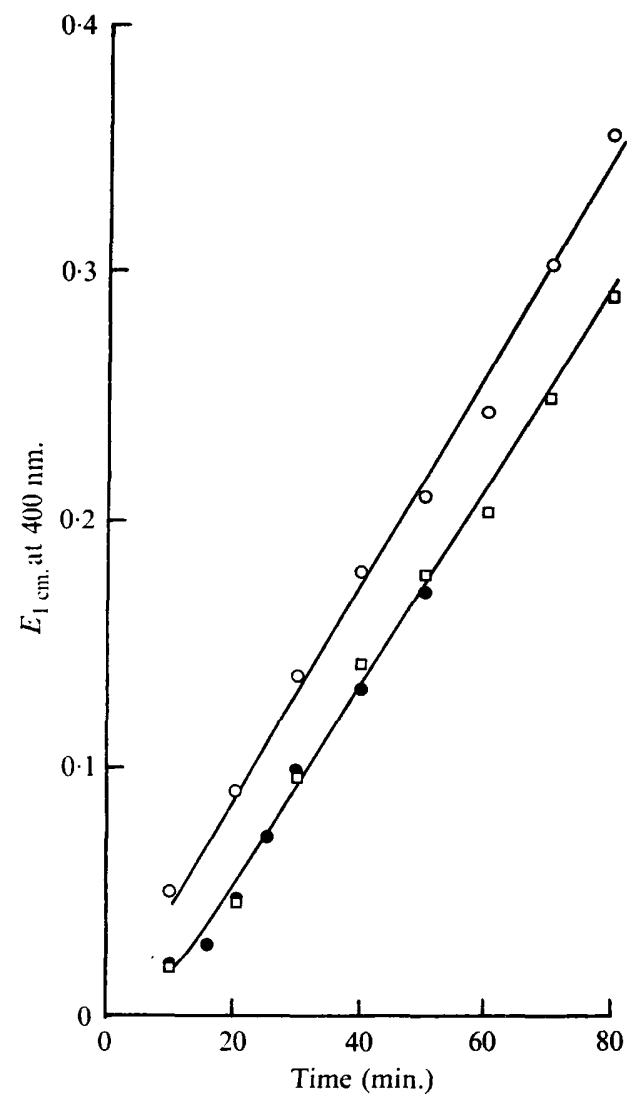

Fig. 3. The liberation of ammonia from Io mM-L-asparagine when Escherichia coli ATCC I I 303 which was grown on Plate Count Agar at $30^{\circ}$ for 2 days, was incubated with asparagine at $37^{\circ}$ in $0.05 \mathrm{M}$-borate buffer $\mathrm{pH} 8.5(-\mathrm{O}-\mathrm{O}-$ ) and the lag produced when a disrupted (Hughes, 195I) preparation of the same organisms was incubated under these conditions $(-\square-\square-)$. The lag was not avoided by incubating the disrupted bacteria in the buffer for $20 \mathrm{~min}$. before adding asparagine (-O- - .

\section{L-Asparaginase activities of bacteria}

The results of these preliminary studies showed that the degradation of $L$-asparagine and L-glutamine by suspensions of whole bacteria occurs at a uniform rate and provides in most cases a reliable measure of the total complement of amidase in the cell. The screening procedure was therefore applied to fresh preparations of bacteria which had been grown to maturity on Plate Count Agar. 
The results are summarized in Table 4. Where more than one value is given against a strain, the values were obtained from different cultures of the bacterium and determined on different occasions. Particular attention was paid to strains of Escherichia coli, Serratia marcescens and Erwinia carotovora, the asparaginases from which have been used clinically.

\title{
Table 3. Protective effect of anaerobiosis and EDTA upon the stability of asparaginase in a soluble extract from Escherichia coli
}

\begin{abstract}
A soluble fraction (about $5 \mathrm{mg}$. protein $/ \mathrm{ml}$.) from $E$. coli ATCC I 1303 was stored at 2 to $4^{\circ}$ for 17 days in the absence or presence of 5 mM-reducing agent and Io mM-EDTA. Anaerobic conditions were obtained by storing the solutions in Thunberg tubes which were then evacuated to remove dissolved gases and sealed. Aerobic conditions were maintained for solutions in similar tubes by allowing access to air. Enzyme activity was determined by the test tube method.
\end{abstract}

\begin{tabular}{|c|c|c|c|}
\hline \multirow[b]{3}{*}{ Reducing reagent } & \multicolumn{3}{|c|}{ Enzyme activity (i.u./mg. protein) } \\
\hline & \multirow[b]{2}{*}{$\begin{array}{c}\text { Anaerobic } \\
\text { without EDTA }\end{array}$} & \multicolumn{2}{|c|}{ Aerobic } \\
\hline & & without EDTA & with EDTA \\
\hline None & 0 & 0 & $\mathbf{I} \cdot \mathbf{I}$ \\
\hline Ascorbic acid & $I \cdot 0$ & 0 & $I \cdot 2$ \\
\hline Thiogycollic acid & $1 \cdot 2$ & 0 & $I \cdot I$ \\
\hline Glutathione & $1 \cdot 2$ & 0.31 & $I \cdot I$ \\
\hline Cysteine & 0.68 & 0.09 & $I \cdot I$ \\
\hline
\end{tabular}

Of the species examined those from the genus Erwinia displayed the highest activity. Bacteria with very low activities appeared irregularly throughout the different groups of bacteria.

\section{L-Glutaminase activities of bacteria}

Specific glutaminases from Escherichia coli, Proteus morganii and Clostridium welchii have optimal activities at about pH 5 (see Hughes \& Williamson, 1952). Such enzymes however would be unsuitable for clinical use where they would be required to operate at $\mathrm{pH} 7 \cdot 5$. The clinically effective glutaminases described by Roberts et al. (I97I $b$ ) and Broome (1971) have optima above neutrality. Screening for glutaminase was therefore carried out at $\mathrm{pH} 8.5$ under similar conditions to those used for the assay of $\mathrm{L}$-asparaginase. At this $\mathrm{pH}$, bacteria appear to be generally less active towards L-glutamine than towards L-asparagine and none of the species examined displayed high levels of glutaminase activity (Table 5).

All the bacterial asparaginases which have been characterized have significant levels of glutaminase activity.

During the clinical evaluation of asparaginases from Escherichia coli and Erwinia carotovora, a low order of activity towards L-glutamine has at different times been thought responsible for toxic side-effects and has been credited with therapeutic activity. It was of interest therefore to obtain a series of asparaginases with different degrees of activity towards L-glutamine. Several strains of Erwinia carotovora were examined for the purpose of selecting those which were likely to provide such a series. Determinations of both L-asparaginase and L-glutaminase on common suspensions of these strains revealed wide differences among them (Table 6).

It is likely that the differences observed between these strains of Erwinia carotovora reflect differences in the specificities of a single enzyme for the amides rather than differences in the relative quantities of a specific glutaminase and an asparaginase, since the ratio 


\section{Table 4. Asparaginase activities of bacteria}

Bacteria were grown on Plate Count Agar at $30^{\circ}$ for 2 days and asparaginase activity determined by the automated method.

\section{Species}

Rhodopseudomonas spheroides

Thiobacillus denitrificans

Pseudomonas aeruginosa

$P$. angulata

P. chlororaphis

P. cichorii

$P$. fluorescens

$P$. fluorescens

$P$. iodinum

$P$. lemonnieri

$P$. milden

P. maculicola

$P$. morsprunorum

$P$. phaseolicola

$P$. primulae

P. putida

$P$. syncyanea

$P$. syringae

Xanthomonas begoniae

$X$. campestris

$X$. juglandis

$X$. hederae

$X$. pelargonii

Aeromonas hydrophila

A. liquefaciens

Azotomonas insolita

Mycoplana bullata

$M$. dimorpha

Alcaligenes bookeri

A. faecalis

A. viscolactis

A. metalcaligenes

Escherichia coli

E. coli

Citrobacter freundii

C. freundii

C. intermedia Type I

C. intermedia Type II

Aerobacter aerogenes

Erwinia amylovora

E. aroideae

E. aroideae
E. aroideae
E. atroseptica
E. atroseptica
E. atroseptica
E. carnegieana
E. carnegieana

Strain

NCIB 8253
MRE 1106
ACTC 7700, NCTC I999, NCIB 8626
FD 496
NCIB 9402
NCPPB 907
KB I

NCTC 8248, 8729

NCDO 754

NCIB 8917

NCDO 754

NCPPB 952

FD 644

NCPPB 52

NCPPB I 33

C I B

NCDO 795

FD 495

NCPPB 24I

NCPPB 528

ICPB XJ 107

ICPB XH I

ICPB XP I 2 I

NCMB 72

NCMB 87

NCIB 8627

ATCC 4278

NCIB 9439

ATCC 15099

ATCC 8748

ATCC 9036

NCIB 9018

ATCC I 1303

MRE I6I, I65

NCIB 8269, 900I, 9270

NCTC I 639

MRE I62/6, I 64

NCTC 8164, 8196

NCTC 6071

NCTC 81 65

NCIB 3735

NCIB 6071

MRE OOI 3

NCPPB 595

NCPPB 495, 497, 61 2 , I 275, I 276, I 639

NCPPB 340, 370, 37I, 499, 5I 4, 547, 929, 956, I 230, I 23 I

NCPBB 66, 355, 493, 494,

$498,546,550,552,1236$

NCPPB 274, 276, 309, 334,

433,435, I 277

NCPPB I 38, 31 3, 437, 979,

I 640, 2043

NCPPB 1590

NCPPB 67I

NCPPB 672
L-Asparaginase activity

(i.u./mg. protein)

$<0.03$

$<0.03$

$0.17-0.23$

0.21

0.13

$0.15,0.1$

$0.15,0.12$

$0.15-0.17$

$0.08,0.19$

0.13

$0.06,0.05$

$<0.02$

$0.02,<0.03$

0.10

O. I I

0.24

0.025

0.19

0.06

0.066

$0.1,0.04,0.03$

0.03

0.10

$<0.04$

O. IO

$0.10,0.08$

0.06

$<0.02$

0.1 I

0.05

$0.13,0.19,0.10$

$<0.03,0.05$

$0.08-0$. I I

$0.12-0.18$

$0.31,0.27$

$0.55,0.5 \mathrm{I}$

0.38

0.74

$<0.03$

0.43

$0.2 \mathrm{I}-0.5$

$0.53-I \cdot 5$

I $\cdot 6-3 \cdot 8$

$0.21-0.4 \mathrm{I}$

$0.59-0.88$

$2 \cdot 4$

$0.02,0.11$

0.10 
Table 4 (cont.)

Species
E. carotovora
E. carotovora
E. carotovora
E. carotovora
E. chrysanthemi
E. chrysanthemi
E. chrysanthemi
E. cypripedii
E. cypripedii
E. cypripedii
E. cytolytica
E. maydis
E. nigriflavens
E. rhapontica
E. rhapontica
E. uredovora
Serratia kiliense
$S$. marcescens

\section{S. marcescens}

Proteus vulgaris

P. vulgaris

Micrococcus conglomeratus

$M$. freudenreichii

M. lysodeikticus

$M$. radiodurans

Sarcina aurantiaca

$S$. flava

S. lutea

$S$. species

Streptococcus faecalis

$S$. faecalis

Lactobacillus casei

Corynebacterium fascians

C. viscosum

C. xerosis

Microbacterium lacticum

Arthrobacter aurescens

A. citreus

Bacillus cereus

B. circulans

B. coagulans

B. lentis

B. megaterium

B. pumilus

B. sphaericus

B. subtilis

Nocardia coelica

$N$. erythropolis

Thermopolyspora glauca
Strain

NCPPB I 281, 1625, 1743, I746,

$1747,1791,1847,2042$

NCPPB 49I , 5I 6, I 280, I 744,

I 748, I 848, I 860

NCPPB 3I 2, 392, 395, 438, 468,

898, I 740, I 74I, I 742

NCPPB 551, 708, 1065, 1066 ,

I I 20, I I 2 I, I I 25

NCPPB 394, 402, 426, 430,

$533,910,911$

NCPPB 395, 429, 5I I, 5I 7, 5I8,

$568,1515,2027$

NCPPB 913

NCPPB 74I

NCPPB 750

NCPPB 752

NCPPB I 385

NCPPB I85I

NCPPB 564

NCPPB 139

NCPPB I 578, 1739

NCPPB 1416

NCTC 4619

JA I 30, I 3 I, I 50, I 90, 280, 440, MRE UK8, NCIB 46I 2 , 8266,8889

JA I10, I 40, 200, 2 I0, 230, 260, 3 I I , 32 I, 430, NCIB 9155

MRE 402, NCTC 1635, 8065, 8066

ATCC I 2454, I 3315

NCIB 2677

NCIB 2699

ATCC 4698, NCTC I 377

ATCC 13939

ATCC 146

MRE strain

MRE 304, NCTC 7564

NCTC 7582

MRE 297

NCIB 6782

NCIB 4 I I 3

NCPPB I 488

NCTC 2416

ATCC 9755

NCIB 8540

NCIB 8912

NCIB 8915

NCTC 7464

NCTC 7578

NCTC 399 I

NCTC $\mathbf{4 8 4 2}$

NCTC 2607

NCTC 7576

NCTC 7582

MRE strain

NCIB 8939

NCIB 9 I 5 I

RES A 66
L-Asparaginase

activity

(i.u./mg. protein)

$0.2-0.6$

$0.7-0.95$

I $\cdot I-I \cdot 6$

$2 \cdot 9-5 \cdot 3$

$0.11-0.39$

$0.4-0.66$

$1 \cdot 6$

0.17

0.39

0.08

0.29

$3 \cdot 3$

0.15

0.19

$0.06-0.08$

0.27

$0.14,0.12$

$0 \cdot 18-0.30$

$0.3 I-0.47$

$0.15-0.46$

$0.61-0.63$

0.10

$<0.05$

$0.12-0.17$

0.10

0.25

0.12

$0.05-0.08$

0.013

$0.14,0.17$

$<0.02$

$<0.02$

0.34

0.16

0.07

0.05

0.04

0.1 I

0.15

$0.03,<0.02$

0.03

0.10

$0.31,0.12$

0.80

0.04

0.50

I. I

I. 5

$<0.05$ 


\section{Table 5. L-Glutaminase activities of bacteria}

Bacteria were grown on Plate Count Agar at $30^{\circ}$ for 2 days and L-glutaminase activities determined by the automated method at $\mathrm{pH} 8 \cdot 5$.

Species

Rhodopseudomonas spheroides

Pseudomonas fluorescens

Xanthomonas juglandis

Aeromonas liquifaciens

Alcaligenes metalcaligenes

Escherichia coli

E. coli

Aerobacter aerogenes

Serratia marcescens

Proteus vulgaris

Micrococcus lysodeikticus

Bacillus megaterium

B. subtilis
Strain

NCIB 8253
NCTC 8729
ICPB XJ IO
NCMB 87
NCIB 9018
ATCC 11303 , NCTC 8164,900 I
MRE $162 / 6,165$
MRE OOI3
NCIB 8889
NCTC 8065
ATCC 4698
NCTC 2607
MRE Strain

L-Glutaminase activity

(i.u./mg. protein)

$<0.03$

0.077

$<0.033$

0.04

$<0.03$

$0.02-0.03$

$0.046-0.065$

$<0.03$

0.06

0.025

0.05

0.026

0.033

Table 6. L-Glutaminase activities of NCPPB strains of Erwinia carotovora

Bacteria were grown on Plate Count Agar at $30^{\circ}$ for 2 days and glutaminase and asparaginase activities determined on samples of the same suspension of organisms by the automated method at $\mathrm{pH} 8 \cdot 5$.

\begin{tabular}{|c|c|c|}
\hline & & $\begin{array}{c}\text { L-Glutaminase } \\
\text { activity }\end{array}$ \\
\hline Strain & $\begin{array}{c}\text { L-Glutaminse } \\
\text { activity } \\
\text { (i.u./mg. protein) }\end{array}$ & $\begin{array}{c}\text { L-Asparaginase } \\
\text { activity } \\
(\%)\end{array}$ \\
\hline $3 \mathrm{I} 2$ & 0.03 & $2 \cdot 2$ \\
\hline 392 & 0.04 & $2 \cdot 6$ \\
\hline 395 & 0.03 & $2 \cdot 5$ \\
\hline 438 & 0.036 & $2 \cdot 8$ \\
\hline 468 & 0.028 & $2 \cdot 6$ \\
\hline 49I & 0.034 & 4.9 \\
\hline 516 & 0.089 & II.O \\
\hline $55 \mathrm{I}$ & 0.38 & $8 \cdot 3$ \\
\hline 708 & 0.64 & $14^{\circ} 0$ \\
\hline 898 & 0.14 & $9 \cdot 3$ \\
\hline 1066 & 0.24 & $8 \cdot 2$ \\
\hline I I 20 & 0.70 & 19.0 \\
\hline I I 2 I & 0.33 & $8 \cdot 2$ \\
\hline I I 25 & 0.48 & $9 \cdot 2$ \\
\hline I 280 & 0.095 & 10.0 \\
\hline I 28 I & 0.06 & I I $\cdot 0$ \\
\hline 1625 & 0.033 & $5 \cdot 7$ \\
\hline I 740 & 0.052 & $3 \cdot 8$ \\
\hline I74I & 0.046 & $3 \cdot 9$ \\
\hline 1742 & 0.045 & $4^{\cdot I}$ \\
\hline I 743 & 0.06 & 33.0 \\
\hline I 744 & 0.036 & $5 \cdot 3$ \\
\hline I 747 & 0.044 & $7 \cdot 3$ \\
\hline 1746 & 0.108 & 26.0 \\
\hline I 748 & 0.057 & 6.0 \\
\hline I 79I & 0.085 & $37 \cdot 0$ \\
\hline I 847 & 0.07 & $3 I \cdot 0$ \\
\hline I 860 & 0.05 & $6 \cdot 7$ \\
\hline I 848 & 0.059 & $9 \cdot 6$ \\
\hline 2042 & 0.037 & $6 \cdot 6$ \\
\hline
\end{tabular}


of glutaminase to asparaginase activity in a purified asparaginase from $E$. carotovora NCPPB 1066 and in partially purified preparations of the enzyme from $E$. carotovora NCPPB 312 and I 120 are of the same order as the ratio of these activities in the intact bacteria (Table 6).

\section{DISCUSSION}

The data in Table 2 support the general belief that the activities of most microbial asparaginases are fully expressed in the intact organism and suggest that these enzymes are generally located in the periplasm like the antitumour asparaginase from Escherichia coli (Cedar \& Schwartz, 1967). In applying the assay to whole organisms, however, any cytoplasmic asparaginases that are present will be overlooked. This is of no more than theoretical interest since such asparaginases, like the cytoplasmic asparaginase from E. coli (Cedar \& Schwartz, 1967), are unlikely to have a high affinity for asparagine (in competition with protein-synthesizing enzymes) and unlikely therefore to be of much therapeutic value (Broome, 1968).

The choice of buffer for the determination of enzyme took account of the fact that those bacterial asparaginases which have been characterized have optima above neutrality and that the presence of borate ions and EDTA would discourage growth and the assimilation of ammonia during the period of incubation. The borate ion is in fact more toxic to the growth of bacteria than nitrite or fluoride ions (Porter, 1946).

The low concentration of glucose ( $(.1 \%)$ in Plate Count Agar used for the comparison of species in Tables 4 to 6, encouraged in most species a rapid initial rate of growth before the bacteria became dependent upon amino acids and peptides for a source of energy. The presence of this level of glucose appeared to be essential for the production of L-asparaginase from Escherichia coli growing in a casein hydrolysate medium and its exhaustion preceded the synthesis of the enzyme (Robison \& Berk, I969).

The depressing effects of higher concentrations of carbohydrates (Table I) has been observed by others. Roberts, Burson \& Hill (1968) showed that the addition of carbohydrates to a medium of corn-steep liquor reduced the production of asparaginase by Escherichia coli. A similar observation was made with Serratia marcescens (Heinemann \& Howard, 1969). It is difficult from batch cultures such as these to establish whether the low yield of asparaginase is the result of an excess of carbohydrate or of a low $\mathrm{pH}$. Continuous cultures of $S$. marcescens and Erwinia carotovora, however, have indicated that the concentration of carbohydrate is primarily responsible (D. Herbert, D. S. Callow and C. G. T. Evans, private communication).

The high yields of asparaginase obtained with unsupplemented Plate Count Agar, discouraged studies into methods for inducing the enzyme. The production from Escherichia coli was not increased when a complex medium (Roberts et al. 1968; Robison \& Berk, 1969) or an amino acid free medium (D. Herbert, private communication) were supplemented with L-asparagine. Only among species of Pseudomonas has there been any evidence of a marked induction by asparagine or aspartic acid (Zanin, Berezov, Nikolaev \& Abdumalikov, 1969).

The use of a nutrient agar simplified the screening process by avoiding the necessity for washing the bacteria. Bacteria transferred directly from its surface into buffer introduced negligible quantities of ammonia and other interfering substances from the medium and thus avoided the need for a substrate-free control in the enzyme assay. Such a control could not be omitted with suspensions which had been stored as pastes at 2 to $4^{\circ}$ or with preparations of disrupted bacteria. 
The levels of asparaginase reported here are generally of the same order as those reported from liquid cultures of similar composition by Peterson \& Ceigler (1969) and Zanin et al. (1969) but are generally lower than those reported by Roberts et al. (1968) from cornsteep liquor. The general conclusion of these data and those set out in Tables 4 and 5 is that L-asparaginase and L-glutaminase are very common among bacteria. The results offer only a little help to taxonomy but establish the existence of a relatively few species which are capable of intense asparaginase activity.

Several species of bacteria have received special attention with a view to the therapeutic use of their amidases. One of the first was Pseudomonas aeruginosa (Greenberg, Blumenthal \& Ramadan, 1964). Its amidase has antitumour activity and showed about equal activity towards L-asparagine and L-glutamine. A similar enzyme has been described in several reports by Mardashev (see Mardashev, Eremenko \& Nikolaev, 1970). An amidase from a species of Xanthomonas has a greater activity towards L-glutamine; its extremely high affinity for both substrates makes it very effective against tumours (Broome, I97I). A similar nonspecific amidase has been purified from a Gram-negative species of Diplococcus by Roberts, Holcenberg \& Dolowy (I97I $a$ ). None of the Pseudomonadaceae examined showed very high levels of asparaginase activity (Table 4 ).

The increase in asparaginase activity observed when suspensions of Alcaligenes viscolactis were disrupted (Table 2) suggests either the presence of a significant amount of enzyme in the cytoplasm or the ability of the whole organism to assimilate ammonia under the alkaline conditions of the assay. The generally low values observed in this genus (Table 4) may therefore be underestimates of the enzyme content.

The purification of L-asparaginase from Escherichia coli brought to light the existence of two asparaginases in this species, only one of which exhibits antitumour activity (Roberts, Prager \& Bachynsky, 1966; Schwartz, Reeves \& Broome, 1966; Campbell, Mashburn, Boyse \& Old, I967). Using strain K I2, Cedar \& Schwartz (1967) showed that the ineffeciive one is not released upon forming sphaeroplasts and is therefore probably located in the cytoplasm.

The strains of Escherichia coli examined here (Table 4 ) are not very active against Lasparagine, much higher activities have been reported in other media. Strain ATCC II303, for example, produced more than ten times the level reported here when grown on corn-steep liquor (Roberts et al. 1968). Under the standard growth conditions used for screening, the citric acid assimilating species of Citrobacter, $C$. freundii and $C$. intermedia, produce higher levels of asparaginase than $E$. coli. A modification of the conditions of growth would perhaps widen this distinction and provide a quantitative character of taxonomical value.

The measurement of asparaginase activity may be of more immediate benefit for distinguishing species of Erwinia from strains of Escherichia coli. In contrast to the latter, many strains of Erwinia exhibit high levels of asparaginase activity (Table 4). Of these, strains of Erwinia carotovora, $E$. aroideae and $E$. maydis produce the highest. The early examination of species of Erwinia in the screening programme was prompted by the knowledge that Lasparagine is a common plant storage product and the thought that some plant pathogens would be well equipped to degrade it. In the event, however, there appears to be no simple correlation between the asparaginase activity of a strain and the likely asparagine content of its host plant.

Strains of Serratia marcescens display exceptionally uniform levels of asparaginase activity (Table 4). An early demonstration of antitumour activity by Rowley \& Wriston (I967) prompted the large-scale production of this enzyme (Heinemann \& Howard, 1969).

Of the species of Bacillus examined, Bacillus pumilus and B. subtilis were distinguished by 
high asparaginase activities (Table 4). The asparaginase of $B$. coagulans was isolated and shown to have no antitumour activity by Mashburn \& Wriston (1964). This and the observations of others led to an appreciation of the special properties which are essential for the expression of this activity (Broome, 1968; Rutter \& Wade, I97I).

The Nocardia species (Table 4) appear to contrast with species of Actinomyces examined by Zanin et al. (1969), in having prominent asparaginase activities.

We are indebted to $\mathrm{Mr} \mathrm{W}$. J. Brent for technical assistance. The work was supported by a grant from the Department of Health and Social Security.

\section{REFERENCES}

Broome, J. D. (196I). Evidence that the L-asparaginase activity of guinea pig serum is responsible for its antilymphoma effects. Nature, London I9I, II I4-I I I5.

BRoome, J. D. (1968). Factors which may influence the effectiveness of L-asparaginases as tumour inhibitors. British Journal of Cancer 22, 595-602.

Broome, J. D. (I97I). Relationship between L-asparaginase and L-glutaminase in tumour inhibition. In Colloque sur la L-asparaginase. Colloque du CNRS no. 197. Paris: Edition du Centre National de la Recherche Scientific.

Campbell, H. A., Mashburn, L. T., Boyse, A. E. \& Old, L. J. (1967). Two L-asparaginases from Escherichia coli B. Biochemistry 6, $72 \mathrm{I}-730$.

CAPIZZI, R. L., Bertino, J. R. \& HANDSChumacher, R. E. (1970). L-Asparaginase. Annual Review of Medicine 2I, 433-444.

Cedar, H. \& Schwartz, J. H. (1967). Localisation of the two L-asparaginases in anaerobically-grown Escherichia coli. Journal of Biological Chemistry 242, 3753-3755.

COONEY, D. A. \& HANDSChumACHER, R. E. (1970). L-Asparaginase and L-asparagine metabolism. Annual Review of Pharmacology 10, $42 \mathrm{I}-439$.

El-Asmar, F. A. \& Greenserg, D. M. (I966). Studies on the mechanism of inhibition of tumour growth by the enzyme glutaminase. Cancer Research 26, I I6-I 22.

Greenberg, D. M., Blumenthal, G. H. \& Ramadan, M. A. (I964). Effect of administration of the enzyme glutaminase on the growth of cancer cells. Cancer Research 24, 957-963.

Heinemann, B. \& Howard, A. J. (1969). Production of neoplastic tumour inhibitory enzyme L-asparaginase by submerged growth of Serratia marcescens. Applied Microbiology 18, 550-554.

Hughes, D. E. (195I). A press for disrupting bacteria and other micro-organisms. British Journal of Experimental Pathology 32, 97-109.

Hughes, D. E. \& Williamson, D. H. (1952). Some properties of the glutaminase of Clostridium welchii. Biochemical Journal 5I, 45-55.

KIDD, J. G. (1953). Regression of transplanted lymphomas induced in vivo by means of normal guinea pig serum. Journal of Experimental Medicine 98, 565-582.

Koch, F. C. \& McMeexin, T. L. (I924). A new direct nesslerization micro Kjeldahl method and a modification of the Nessler-Folin reagent for ammonia. Journal of the American Chemical Society 46, 20662069.

Mardashev, S. R., Eremenko, V. V. \& Nikolaev, A. YA. (1970). Identification of Pseudomonas species and the effect of growth conditions on aspartase and glutaminase activity. Microbiology 39, 6-1 I.

MASHBURN, L. T. \& WRISTON, J. C. (1964). Tumour inhibitory effect of L-asparaginase from Escherichia coli. Archives of Biochemistry and Biophysics 105, 450-452.

Mickle, H. (1948). Tissue disintegrator. Journal of the Royal Microscopical Society 68, 10-1 2.

Peterson, R. E. \& Ceigler, A. (1969). L-Asparaginase production by various bacteria. Applied Microbiology I7, 929-930.

PORTER, J. R. (1946). Bacterial Chemistry and Physiology, p. 255. New York: John Wiley.

RILEY, V. (1970). Influence of a benign virus upon mouse leukaemia during asparaginase therapy. Pathologie Biologie 18, 757-764.

RoBerts, J., BURSON, G. \& Hill, J. M. (I968). New procedures for purification of L-asparaginase with high yield from Escherichia coli. Journal of Bacteriology 95, 21 1 7-21 23.

RoBERTS, J., HolcenBerG, J. S. \& Dolowy, W. C. (197I $a$ ). Glutaminase induced prolonged regression of established Ehrlich carcinoma. Life Sciences 10, 25I-256. 
Roberts, J., Holcenberg, J. S. \& Dolowy, W. C. (I97I $b$ ). Antineoplastic activity of highly purified bacteria glutaminases. Nature, London 227, I $136-1137$.

Roberts, J., Prager, M. D. \& BAChynsky, N. (1966). The antitumour activity of Escherichia coli L-asparaginase. Cancer Research 26, 221 3-2217.

RoBison, R. S. \& BERK, B. (1969). L-Asparaginase synthesis by Escherichia coli, B. Biotechnology and Bioengineering II, I $21 \mathrm{I}-1225$.

ROWLEY, B. \& WRISTON, J. C. (1967). Partial purification and antilymphoma activity of Serratia marcescens L-asparaginase. Biochemical and Biophysical Research Communications 28, I60-165.

RUtTER, D. A. \& WADE, H. E. (197I). The influence of the isoelectric point of L-asparaginase upon its persistence in the blood. British Journal of Experimental Pathology (in press).

Schwartz, J. H., Reeves, J. Y. \& Broome, J. D. (I966). Two L-asparaginases from E. coli and their action against tumours. Proceedings of the National Academy of Science 56, I 516-I 5 I9.

WADE, H. E. (196I). The autodegradation of ribonucleoprotein in Escherichia coli. Biochemical Journal 78, 457-47I.

Wade, H. E., Elsworth, R., Herbert, D., Keppie, J. \& Sargeant, K. (1968). A new L-asparaginase with antitumour activity. Lancet ii, 776-777.

Wade, H. E. \& Phillips, B. W. (I97I). The automated determination of bacterial asparaginase and glutaminase. Analytical Biochemistry (in press).

Wade, H. E., Robinson, H. K. \& Phillips, B. W. (I97I). The asparaginase activities of bacteria. Journal of General Microbiology 65, i.

WADE, H. E. \& Rutter, D. A. (1970). Asparaginase - treatment for leukaemia. Science Journal 6, $62-67$.

Wriston, J. C. (197I). In The Enzymes, 3rd. edn, vol. IV, p. IoI-117. Edited by P. D. Boyer. New York: Academic Press (in press).

Zanin, V. A., Berezov, T. T., Nikolaev, A. YA \& Abdumalikov, A. Kн. (1969). Formation of L-asparaginase in some micro-organisms. Microbiology 38, 432-436. 